\title{
Improving the Application of Project Management Methods for the Purpose of Implementation of National Projects
}

\author{
L.A. Mustafina ${ }^{1}{ }^{*}$ \\ *Corresponding author: lilsadykva@rambler.ru \\ ${ }^{1}$ Samara State University of Economics, Samara, Russia
}

\begin{abstract}
At the present time, the Government of the Russian Federation is engaged in the development and preparation of a number of national projects aimed at accelerating the social and economic development of the country. In the course of this undertaking, the Government should pay special attention to the technology involved in the projects, which contributes to the relevance of the study. The study aims is to improve the methodology of project technology as a part of public management in the aspect of the implementation of national projects. The main tasks within the study were: reviewing the organizational and management structures of a national project, clarification of the definition of a national project from the perspective of project management. In order to solve the problems stated in the study, empirical and theoretical methods were used, including an analysis of the national regulatory framework and methodology in the field of project management; systematization of organizational and management structures; comparison of project management models for the implementation of comprehensive planning documents as adopted in the Russian Federation. As a result, we have identified a number of features and problems arising in the process of integration of projects at the regional and municipal level, elaborated the concept of a national project, and proposed to introduce it to the Russian legislation.
\end{abstract}

Keywords: national priority project, national project, priority project, project management, organizational structure, national and regional governance.

\section{Introduction}

The Executive Order of the President of the Russian Federation No. 204 "On National Goals and Strategic Objectives of the Russian Federation through to 2024“ [1] has defined a number of national goals and priorities, within which the Government of the Russian Federation takes certain activities to develop and form national projects or programs (hereinafter referred to as national projects) in the following fields of social and economic development of the country: demography, health care, education, housing and urban development, environment, safe and high-quality roads, labor productivity and employment support, science, digital economy, culture, small and medium enterprises and support for individual entrepreneurial initiative, international cooperation and exports. As of today, certain regulations, methodical recommendations and separate financial support were established on the basis of a practical evaluation of the project approach in the activities of executive authorities with regard to the implementation of priority programs or projects (hereinafter referred to as priority project) and in accordance with the Decree of the Government of the Russian Federation dated October 15, 2016 No. 1050 "On the organization of project activities in the Government of the Russian Federation" [2]. In addition to this, a number of measures was taken to educate and improve the competencies of the staff of executive authorities at various levels. All these actions provide a platform for implementing a national project through the use of project management methods.

\section{Problem Statement}

Projects of this kind have been implemented earlier. In 2005, in order to accelerate the development of human capital and improve the quality of life of the population, the President of the Russian Federation identified the main problems in the field of demographic and social policy [3], and they have been addressed within four priority national projects. The experience of the first projects in Russia was considered to be an innovative tool and set the pace for the new format of operation of management teams within executive authorities, aiming to achieve the set goals. The results of the activities that had been implemented within the framework of national priority projects were neither a breakthrough, nor a failure. The actions taken turned out to be isolated and formal, being unable to overcome the country's urgent and pervasive challenges. This outcome was affected by the unpreparedness of the existing mechanism of government to fundamental shifts in the management structure in a very short time provided for the implementation of the goals of national priority projects. Similar problems have emerged at the local government level as well [4]. Poor organizational and management structure entailed the lack of any methodology, independent regulatory framework or a separate expenditure item on the budget, resulting in inconsistencies between the national priority projects and the principles of project management. The lack of legal status has resulted in goal duplication within government programs and their parallel functioning, which has reduced the level of transparency of operations and the forms of 
implementation of activities of the executive authorities. As a result, there were complications with supervision over the efficiency of the use of budgetary funds and the justification of the implementation of certain measures implemented under the projects referred to above [5]. Considering the substantial flaws in the experience of practical evaluation of project management methods when applied to national-level projects, the need arises to further develop the project management methodology. The importance of this problem is also due to the significant impact of performance of a national project on the value of gross domestic product and competitive performance of the country in the world market.

\section{Research Questions}

The main tasks within the study were as following: systematization of the organizational and management structures of national projects; definition of the concept of a national project, based on the principles of project management; analysis of project management models.

\section{Purpose of the Study}

The study is aimed at the development of a project management methodology based on a comprehensive analysis of the legislative framework, the existing project management methodology, management structures and the forms of their interaction in this field. Particular attention in the study is directed to the consideration of national projects implemented with the use of project management tools.

\section{Research Methods}

The study involves both empirical and theoretical methods. The first group of methods is applied to analyze a number of legislative and other regulatory documents that act as a regulatory framework for the implementation of project activities by executive authorities. We have also analyzed a number of sources describe the methodology of project management in the Russian Federation, including general standards for project management in Russia. The above actions will make it possible to identify and systematize the organizational and management structures. Their consideration is necessary not only to clarify the definition of the national project, but also to analyze changes in the usual bureaucracy in the public sector. According to H. George Frederickson, "New public administration is probably best understood as advocating modified hierarchic systems" [6], and the introduction of project activities implies a modification of public administration in order to improve it. As for theoretical methods, the obtained data was used for the preparation and comparison of project management models using the example of a national project and a governmental program, as well as the structuring of components of these comprehensive strategic planning documents. All the actions performed enable us to elaborate the concept of a national project, consider the differences between different management models, identify problems in the implementation of a national project and achieve the goal of the study.

\section{Findings}

A national project corresponds to the sheer scale of the goals of so-called May Decree issued by the President of the Russian Federation, implying the inclusion of already existing priority projects into the broader structure of a national project. In order to develop general instructions for updating and breaking down activities within projects at the federal level, and later the regional (and respectively the municipal as well), the Chairman of the Government of the Russian Federation approved the Guidelines for Development of a National Project 4072П-П6 [7], as well as a clarification of the Federal Project Office on filling out data sheet forms for national and federal projects [8].

Changes regarding the modification and reduction of sections of the recommended forms for the formalization of national projects and priority projects are due to a more professional use of the philosophy of project management. The process of project preparation and implementation has been significantly optimized and updated, which is a positive trend in improving the application of the project approach. Another very important addition has been reflected in separate paragraphs of the guidelines that were including instructions for drafting projects for constituent entities of the Russian Federation. Local governments of municipalities of the Russian Federation will also be able to use these instructions to create projects within their activities. It is also worth noting an innovation for a constituent entity of the Russian Federation in the form of recommendations on the distribution of functions, differentiation of roles while managing the supervision process and leadership in the implementation of a national project. This is especially important when merging large projects, the components of which are activities carried out by governments at the regional and municipal levels. In other words, the structuring of all elements included in the executive team of the implemented project is simplified. Based on the guidelines, we present the organizational structure of a national project at the regional and municipal levels (Figure 1). 


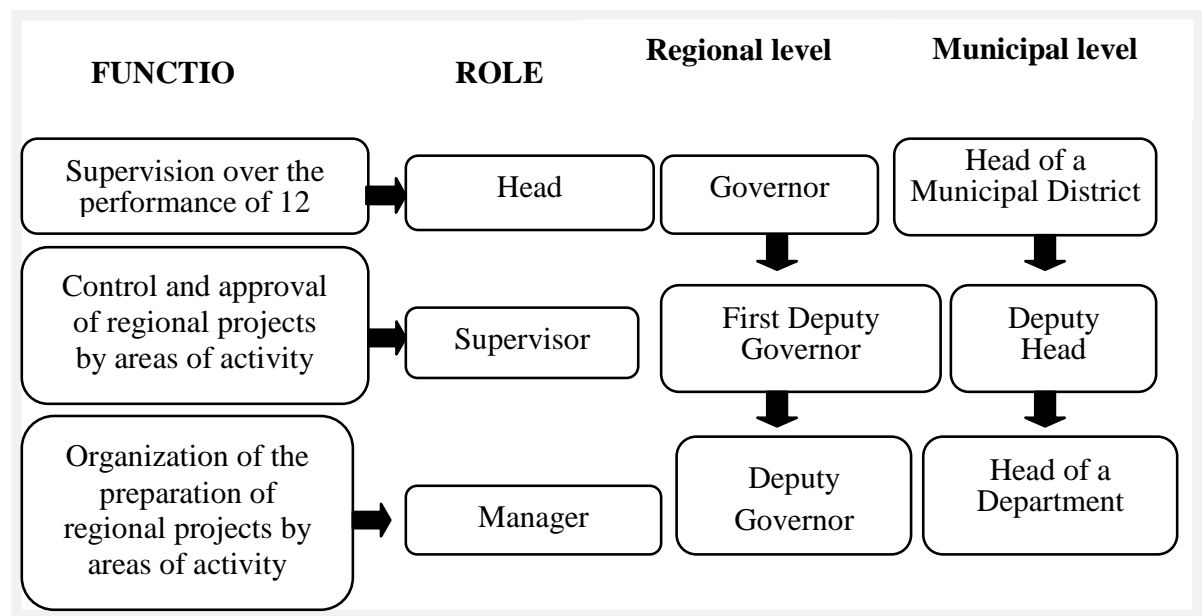

Figure 01. Organizational structure of a national project (Source: compiled by the author)

It is customary to distinguish between process-oriented and project-oriented strategic approaches in public administration. At the moment, state programs have separate process and project parts, each of which has different management mechanisms. The project part has its own group of organizational models, including functional, project and matrix models [9]. The model is built on the principles of interaction and subordination of the functional and project organizational structures to each other. To understand the differences between the above models, we present a comparison of the powers of the head of the project office and the head of the functional unit (department).

This said, a functional model implies the subordination of the entire functional unit engaged in a project within its competencies and activities to a single manager supervising the unit. Heads of functional units answer to the top management, and the head of the project office in this case performs only a general coordinating role. With such an organization, the current activities of the unit are associated with project activities, which is practical and reduces resource costs.

In a project model, the project office has broader functionality, with each project having its own interdepartmental (or intra-departmental) team engaged in the implementation of its own project, and the head of the project office answers to the top management only. In this case, the success will depend on the high professionalism and project skills of the performers.

A matrix model is a more complex model that reflects the dual subordination approach, which implies the subordination of the functional unit to both the head of the functional unit and the head of the project office. The success of the activities under the matrix structure will depend on the competent delegation of authority between the manager and their common responsibility to the top management.

Based on Figure 1, the supervision over the execution of a departmental project becomes the authority not of the department head, but that of the higher management, since a national project includes large projects that provide for a set of joint activities of two or more departments. The higher management uses its authority to regulate the process of exchange and contact between the functional structures. This, of course, preserves the hierarchical system and clearly reflects the imperfect level of interdepartmental interaction, which meets the characteristics of a bureaucracy and most often falls in line with the process approach to management. At the same time, from the standpoint of the project management technology, a national project involves a functional model of the organizational structure.

Decrees of the Government of the Russian Federation No. 1242 [10] and No. 1243 [11], as well as Decree of the Government of the Russian Federation No. 1030 "On the Management System for the Implementation of the Program "Digital Economy of the Russian Federation"' [12] established the principle of inclusion of priority projects in the structure of governmental programs. In addition, priority project is referred to in the amendments made to the Order of the Ministry of Finance of the Russian Federation No. 65H "On Approval of the Guidelines for the Procedure for Applying the Budget Classification in the Russian Federation" [13] as a structural component of a governmental program, together with departmental programs and events.

Therefore, it may be useful to compare project management models used in government programs and national projects to elaborate the differences between different projects integrated into complex planning documents. To do this, we use the requirements of project management standards GOST R 54871-2011 [14] and GOST R 54870-2011 [15], and the provisions of the existing methodology of project activities approved by the Government of the Russian Federation:

- a project portfolio is defined as a set of components grouped together with the purpose of improving management efficiency to achieve strategic goals;

- a project program is defined as a set of interrelated projects and activities combined to achieve a common goal and implemented in the context of common constraints.

Figure 2 illustrates the project management models in the structure of strategic documents. 


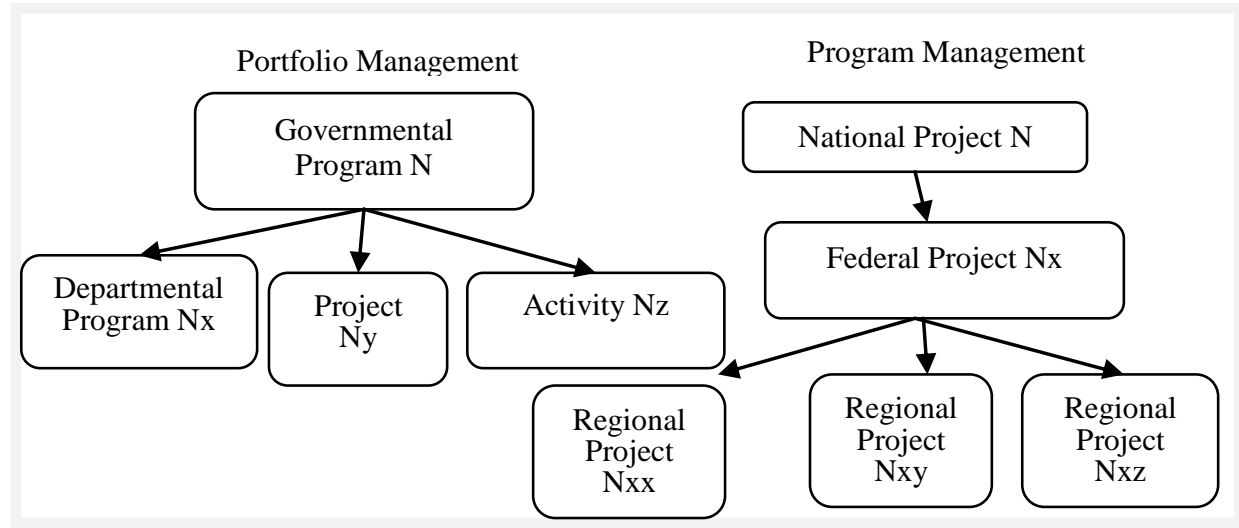

Figure 02. Comparison of project management models project (Source: compiled by the author)

Thus, if we consider a national project from the point of view of the project management methodology, its definition needs to be clarified as follows: a national project is a program of interdependent projects aimed at addressing priority strategic problems of the national level under the conditions of given requirements and resource constraints in order to implement effective social and economic policies and ensure the national security of the country.

\section{Conclusion}

The result of the study is the elaboration of the concept of a national project. Taking into account the direct dependence of the success of the implementation of a national project on the level of efficiency of interaction between regional governments and federal executive authorities, it is important to develop the regulatory framework for project activities to serve as the basis for coordination and collaboration of all branches of government. Considering that the terms "priority project" and "national project" do not have any legal status as strategic planning documents, it is advisable to legally establish the terms "national project (program)", "federal project (program)", "regional project (program)", "municipal project (program)". This will provide the framework for the development and improvement of the methodology of modern public management.

\section{References}

1. Ukaz Prezidenta Rossijskoj Federatsii "O national'nyh thelyah i strategicheskih zadazah razvitiya" ot 07.05.2018 N 204. Retrieved from: http://www.consultant.ru/document/cons_doc_LAW_297432// Accessed: 25.10.2018 (2018). [in Rus.].

2. Postanovlenie Pravitel'stva Rossijskoj Federatsii "Ob organizatcii proectnoy deyatel'nosti v Pravitel'stve Rossijskoj Federatsii" ot 15.10.2016 N 1050. Retrieved from: http://www.consultant.ru/document/cons_doc_LAW_206009/ Accessed: 10.10.2018 (2016). [in Rus.].

3. Rasporyazhenie Pravitel'stva Rossijskoj Federatsii "O Programme sotsialno-economichescogo razvitiya Rossijskoj Federatsii na sredne-srochnyyu perspectivy" ot 19.01.2006 N 38-p. Retrieved from: http://www.consultant.ru/document/cons_doc_LAW_58275/Accessed: 18.09.2018 (2006). [in Rus.].

4. E.N. Koroleva, O.V. Senchuk, A.A. Grankina, Municipal mega-project as a tool for effective use of the potential of rural areas. Regionology, 25(3), 379-392. URL: http://regionsar.ru/ru/node/1610/ (2017).

5. V.I. Dobrosotcky, Improvement of project management in Russia. Management Issues, 49(6), 889-915. URL: http://vestnik.uapa.ru/ru/issue/2017/06/11/ (2017).

6. H.G. Frederickon, The path to new governance. In J.M. Shafritz \& A.C Hyde, (Eds), Classics of the Theory of Public Administration: American school. (pp. 423-433). Moscow, Russia. Moscow University Presse (2003).

7. Metodicheskie reccomendatcii po razrabotke nathionalnyh proectov (programm) dlya realizatsii mayskogo Ukaza ot 04.06.2018 N 4072п-П6. Retrieved from: http://www.consultant.ru/document/cons_doc_LAW_300277/ Accessed: 15.10.2018 (20128). [in Rus.].

8. Pis'mo Apparatta Pravitel'stva Rossijskoj Federatsii "O napravlenii razyasneniy Federal'nogo proectnogo ofisa po zapolneniu form pasportov nathionalnyh federalnyh proectov" ot 13.06.2018 N П6-29821. Retrieved from: http://www.consultant.ru/document/cons_doc_LAW_308954/ Accessed: 25.10.2018 (2018). [in Rus.].

9. I.A. Ratkovskaya, Features of organizational structures within project management. The Journal Of Public ahd Municipal Administration, 3(22), 79-83. DOI: 10.12737/23809 (2016).

10.Postanovlenie Pravitel'stva Rossijskoj Federatsii "O razrabotke, realizathii $i$ ob otcenke effectivnosti otdelnyh gosydarstvennyh programm Rossijskoj Federatsii" ot 12.10 .2017 N 1242. Retrieved from: http://www.consultant.ru/document/cons_doc_LAW_280803/ Accessed: 15.10.2018 (2017). [in Rus.]. 
11.Postanovlenie Pravitel'stva Rossijskoj Federatsii "O realizathii meropriyatiy federalnyh thelevyh programm, integriryemyh $v$ otdel'nye gosudarstvennye programmy Rossijskoj Federatsii" ot 12.10.2017 N 1243. Retrieved from: http://www.consultant.ru/document/cons_doc_LAW_280802/ Accessed: 15.10.2018 (2017). [in Rus.].

12.Postanovlenie Pravitel'stva Rossijskoj Federatsii "O sisteme upravleniya realizathiey programmy "Thifrovaya economica Rossijskoj Federatsii" ot 28.08.2017 N 1030. Retrieved from: http://www.consultant.ru/document/cons_doc_LAW_223702/ Accessed: 19.10 .2018 (2017). [in Rus.].

13.Prikaz Ministerstva Finansov Rossijskoj Federatsii "Ob utverzhdenii ukazaniy o poryadke primeneniya byudzhetnoy classificatsii Rossijskoj Federatsii" ot $01.07 .2013 \mathrm{~N} 65 \mathrm{H}$. Retrieved from: http://www.consultant.ru/document/cons_doc_LAW_148920/ Accessed: 20.09 .2018 (2013). [in Rus.].

14.Prikaz Ministerstva promushlennosti i torgovli Rossijskoj Federatsii "Ob utverzhdenii nathional'nogo standarta "Proectnyy menedzhment. Trebovaniya $k$ upravleniy programmoy"" ot 22.12 .2011 N 1584-cr. Retrieved from: http://docs.cntd.ru/document/902331113 Accessed: 09.2018 (2011). [in Rus.].

15.Prikaz Ministerstva promushlennosti i torgovli Rossijskoj Federatsii "Ob utverzhdenii nathional'nogo standarta "Proectnyy menedzhment. Trebovaniya $k$ upravleniy portfelem proectov" ot 22.12.2011 N 1583-ст. Retrieved from: http://docs.cntd.ru/document/902331112 Accessed: 01.09.2018 (2011). [in Rus.]. 